\title{
Multidisciplinary and Transdisciplinary Design to Teach Problem Solving Skills
}

\author{
$1^{\text {st }}$ Avia Riza Dwi Kurnia \\ Faculty of Mathematics and Sciences \\ State Universit of Malang \\ Malang, Indonesia. \\ Corresponding author: \\ avia.riza.fmipa@um.ac.id \\ $4^{\text {th }}$ Toto Nusantara \\ Faculty of Mathematics and Sciences \\ State University of Malang \\ Malang, Indonesia. \\ Corresponding author: \\ toto.nusantara@um.ac.id
}

\author{
$2^{\text {nd }}$ Muslimin Ibrahim \\ Postgraduated Dept of Sience \\ Education State Univ of Surabaya \\ Surabaya, Indonesia. \\ Corresponding author: \\ musliminibrahim@unesa.ac.id
}

\author{
$3^{\text {rd }}$ Wahono Widodo \\ Postgraduated Dept of Sience \\ Education State Univ of Surabaya \\ Surabaya, Indonesia. \\ Corresponding author: \\ wahonowidodo@unesa.ac.id
}

\begin{abstract}
Science as a field of science that investigates the universe is closely related to natural phenomena. Natural phenomena exist holistically, not independent, and interrelated. Why is integrated science learning so important? This multidisciplinary learning method can train students to think multidimensional, or holistic. This holistic mindset of learners will be used as a life skill in solving problems in their life. This paper will discuss students' ability to design thematic integration and transdisciplinary approaches in science. The ability to design is done in the development research of learning model: thinking, working, scaffolding, sharing (TWSS). The result of research thinking phase $46 \%$ student attitude excellent and $46 \%$ good. The five groups were able to design thematic integration, in which the two groups were able to design transdisciplinary integration. Through various assistance in the TWSS model phase, students can do the assigned tasks.
\end{abstract}

Keyword-Problem solving skill, multidisciplinary, transdisciplinry design.

\section{INTRODUCTION}

Integrated science was born from the thought of one of the pragmatism pioneers, John Dewey. Pragmatism is a philosophical genre which emphasizes the value of knowledge based on its practical utility. Based on his thinking in pragmatism, John Dewey initiated a progressive education. Progressive education gives more attention to potential students, with the belief that meaningful learning should have relevance to their life. Students must be able to solve their problems in everyday life through inquiry (Titus, 1959: 241).

Science as a field of science that investigates the universe is closely related to natural phenomena. The natural phenomenon going holistically, not independently, interrelated. For example environmental pollution, the event can be discussed from the point of population density, pollutant chemicals, changes in environmental conditions and their effects on health. Indrawati (2009: 30) says this multidisciplinary learning method is able to train students to think multidimensional, or comprehensive. Conventional science learning pattern, discussing natural phenomena partially. This way causes the student's mindset to be fragmented, the way of thinking is narrow, less thorough, not holistic.
Why is integrated science learning so important? This holistic mindset of students will be used as life skills in solving problems in their life (Susiwi, 2007: 1). As humans who will live in the future, to meet the necessities of life, they will face many problems. Problems faced by students in everyday life is very complicated, to find the solution cannot be solved only by one discipline, but multidisciplinary. Integrated learning becomes a tool to train learners in understanding problems and solve them from different perspectives. It can be obtained through scientific work, scientific attitude, working together in groups, learning to interact and communicate (Indrawati, 2009: 36).

Additionally added by Widhy (2013: 10), so that students are able to overcome the increasingly complex life challenges, teachers should be able to train students facing the challenges of 21st-century skills. Partnership for 21st Century Skills (2002) identifies six critical elements for the 21 st century. One of them is the three learning skills that students need; first skills related to information and communication, second, the thinking skill and problem solving, third interpersonal skills and self-organizing skills.

The scientific approach to scientific work and problemsolving skills are explicitly included in the 2013 curriculum. It can be reviewed in the Basic Framework and Curriculum Structure of SMP/MTs: Integration in science and social studies using a transdisciplinary approach in which the boundaries of the discipline are no longer visible because of the concepts of the discipline of science blend in, related to the problems encountered in the vicinity. Integration can also be done with connected models: Integration of concepts between biology, physics, and chemistry (Permendikbud No. 68, 2013: 97).

As per the curriculum's mandate, students should gain experience in learning to solve problems with a transdisciplinary approach. Transdisciplinary is defined as a process characterized by the integration of various disciplines to understand the issue or problem (Unesco, 1998: 31). The investigation of natural phenomena and problem-solving is done through scientific work called a scientific approach. The scientific approach to learning in the 2013 curriculum is presented in order, (1) observing, (2) questioning, (3) 
experimenting, (4) associating, and (5) networking. Implementation can start from any stage. The suggested approaches and learning models are problem-based learning, project-based learning, discovery learning, scientific approach and integrative thematic (Permedikbud No. 81a, 2013: 35). The new curriculum in 2016 still maintains an integrated IPA learning and a scientific approach to this is contained in the Basic and Secondary Education Process Standards (Permedikbud No. 22, 2016: 2 - 3).

In other countries understand the problem or problem from the various scientific point of view called social scientific issues (SSI). Problems in SSI are an unclear problem, a science problem related to aesthetics, ecology, economics, morals, education, culture, and religion. European countries in Denmark, England, France, Romania, Spain, and Cyprus emphasize science literacy and the importance of SSI in their curriculum reform documents. Denmark and the UK are teaching science problems using controversial topics. France, Spain, Cyprus, and Turkey use issues that are not necessarily controversial to teach science (Evagorou et al., 2014: 70).

This paper will discuss the ability of students to design thematic alignment and transdisciplinary approach in science. The ability to design is done in the research development of learning model thinking, working, scaffolding, sharing (TWSS). The purpose of the TWSS model is to improve: 1) Knowledge of the relationships between the various branches in the science, and the relationship of science to the field of study in other disciplines. 2) Able to process, design and organize learning following the scientific context and level of development of learners. 3) The cognitive role of the individual in group work and creating an intensive learning environment to accomplish the task outside of his specialist field with expert help.

The model is implemented in the course of Science Curriculum Development of Junior High School (PK IPA SMP) in Biology Department Faculty Mathematics and Science State University of Malang. The discussion is limited to the results of the effectiveness of module 1 . Module 1 entitled Description 4 Integrated Curriculum Approach and Implementation Example. This module covers four subheadings: 1) Intradisciplinary Approach and Examples in the Indonesian Curriculum, 2) Interdisciplinary Approach and Examples in Indonesian Curriculum, 3) Multidisciplinary Approach (Thematic) and Examples in Indonesian Curriculum, 4) Transdisciplinary Approach and Examples in Indonesian Curriculum. The task that students must do is thematic and transdisciplinary integration. Competence of module 1 is to understand the relationship of science with the field of study in another disciplines cluster.

\section{METHODS}

This research uses quantitative descriptive approach. The type is research development to develop learning models. There are three examination stages in this study, namely exam of validity, effectiveness, and practicality. Model development using ADDIE approach (analysis, design, development or production, implementation or delivery, and evaluation). See Fig. 1 (Branch, 2010:15). The core of the five stages in the evaluation. Each stage can be evaluated and revised, then move on to the next step. The distinctiveness of the ADDIE approach, it has not the dissemination stage. Primarily the feasibility of the product is tested utilizing a cycle of each stage. Each stage can be evaluated so that the product developed meets the criteria of a good product, empirically tested and feasible to use.

Preliminary study 1 was conducted in December 2014 and April 2016, to find learning difficulties data in Science Curriculum Development of Junior High School (Pengembangan Kurikulum IPA SMP - PK IPA SMP) course. In preliminary 2 April 2016, also conducted the observation of learning in one class of PK IPA SMP and interview with 13 students. The purpose interview is to develop curriculum and teaching materials. The result is that the students have never received any material on an integrated model or integrated curriculum approach with objectives to 1) understanding the relationship of science with sub-discipline in another

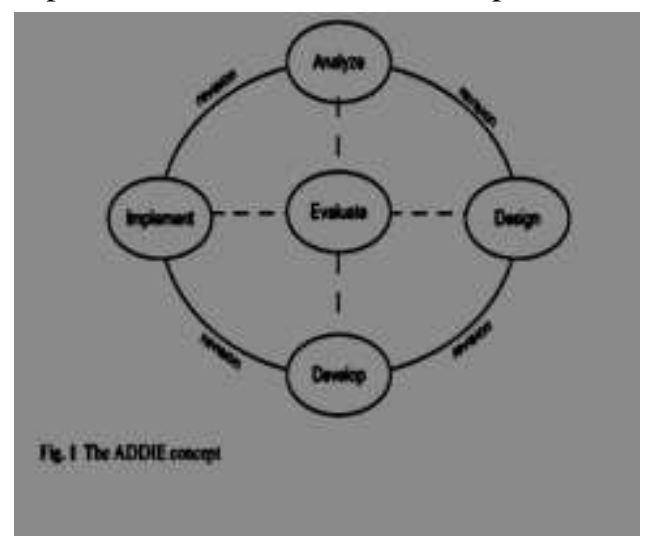

Fig. 1. ADDIE Stage (Branch, 2010:15)

disciplines cluster, 2) understanding the relationship between various sub-disciplines in science and 3) how to design and develop integrated science curriculum into lesson plan. February 2017 researchers interviewed and spread questionnaires to 26 students of PK IPA SMP course. The result is the same as preliminary two, April 2016.

Implementation stage to obtain data of practicality and effectiveness carried out in Department of Biology Faculty of Mathematics and Sciences UM (FMIPA UM). Implementation stage uses two classes of curriculum course of PK IPA SMP. The number of students in each class is 13 people. Each class consists of 3 groups. The study was conducted for one semester, even semester 2016/2017, starting end of January 2017 up to end of May 2017.

Each stage can be evaluated and revised, then move on to the next step. The distinctiveness of the ADDIE approach, it has not the dissemination stage. Primarily the feasibility of the product is tested utilizing a cycle of each stage. Each stage can be evaluated so that the product developed meets the criteria of a good product, empirically tested and feasible to use.

Preliminary study 1 was conducted in December 2014 and April 2016, to find learning difficulties data in Science Curriculum Development of Junior High School (Pengembangan Kurikulum IPA SMP - PK IPA SMP) 
course. In preliminary 2 April 2016, also conducted the observation of learning in one class of PK IPA SMP and interview with 13 students. The purpose interview is to develop curriculum and teaching materials. The result is that the students have never received any material on an integrated model or integrated curriculum approach with objectives to 1) understanding the relationship of science with sub-discipline in another disciplines cluster, 2) understanding the relationship between various sub-disciplines in science and 3) how to design and develop integrated science curriculum into lesson plan. February 2017 researchers interviewed and spread questionnaires to 26 students of PK IPA SMP course. The result is the same as preliminary two, April 2016.

Implementation stage to obtain data of practicality and effectiveness carried out in Department of Biology Faculty of Mathematics and Sciences UM (FMIPA UM). Implementation stage uses two classes of curriculum course of KIPA SMP. The number of students in each class is 13 people. Each class consists of 3 groups. The study was conducted for one semester, even semester 2016/2017, starting end of January 2017 up to end of May 2017.

\section{RESULT DISCUSSION}

Department of Biology Faculty of Mathematics and Science (FMIPA UM) has a primary minor curriculum. Besides the main competence that can teach biology in SMA, Biology Education degree can teach science in junior high school. Several factors must be met so that biology education students can teach science. The first factor is the students of biology education must obtain various prerequisite subjects: 1) Basic Physics, 2) Subject matter science $1 \& 2$ for Junior High School (Materi IPA SMP 1\& 2), 3) Development of Science Curriculum of Junior High School (PK IPA SMP). Second, another significant factor is how to help prospective teachers master the competence of junior high school teachers according to the curriculum's mandate. The TWSS model is one of the solutions to overcome difficulties if the nonscience department has to teach science. TWSS has 4 phases, the description of each stage is described in Table 1.

Table 1. TWSS Model Description

\begin{tabular}{|l|l|}
\hline \multicolumn{1}{|c|}{ Phase } & \multicolumn{1}{c|}{ Description } \\
\hline $\begin{array}{l}\text { Thinking: } \\
\text { the individual } \\
\text { task }\end{array}$ & $\begin{array}{l}\text { When first learning with modules, tutors can help } \\
\text { in the thinking phase. The tutor has to: } \\
\text { 1) Observe student activities and observe student } \\
\text { learning difficulties. 2) If necessary, tutors help in } \\
\text { the form of briefings, so that students can } \\
\text { complete individual tasks. Help instead of } \\
\text { explaining the material. }\end{array}$ \\
\hline $\begin{array}{l}\text { Working: } \\
\text { group tasks }\end{array}$ & $\begin{array}{l}\text { 1) Accompany the students to explain the tasks } \\
\text { listed in the module, 2) guide the group discussion } \\
\text { and 3) guide the group or individual in completing } \\
\text { the task. Help instead of explaining the material. }\end{array}$ \\
\hline $\begin{array}{l}\text { Scaffolding as } \\
\text { cognitive } \\
\text { apprenticeship: }\end{array}$ & $\begin{array}{l}\text { 4) Perform the role of an expert to explain the } \\
\text { problematic material. The tutor will help a more } \\
\text { thorough understanding of integrated curriculum } \\
\text { and 5) link the field of physics with other areas of } \\
\text { group tasks } \\
\text { with tutor } \\
\text { assistance }\end{array}$ \\
\hline $\begin{array}{l}\text { Sharing: } \\
\text { Class } \\
\text { discussion }\end{array}$ & $\begin{array}{l}\text { scaffolding, if students have demonstrated } \\
\text { mastery of tasks, assistance is gradually reduced. } \\
\text { class discussions. }\end{array}$ \\
\hline
\end{tabular}

The TWSS model has two types of scaffolding (see Table 1), in addition to scaffolding as cognitive apprenticeship, assistance also provided in scaffolding as an instructional strategy. The module is first scaffolding instructional form. Second is the attitude of lecturers who aim to help students achieve learning objectives. Scaffolding in the lecturers' attitude is guidance, steps of solving or giving examples and highlighting the critical aspects of the task to be understood, learners. Clear review or encouragement can also be done by lecturers in certain situations.

Modules are designed according to the scaffolding rules, i.e., gradually reducing assistance and promoting selflearning if students have demonstrated improvement skills. The task structure of each module has been adapted to TWSS model. Students were doing independent tasks in the thinking phase, doing group work in the working phase, completing difficult tasks in the scaffolding stage with the assistance of tutors and lecturers and presenting the group work in the sharing stage.

Table 2. Group Ability of Module 1

\begin{tabular}{|c|c|c|c|c|c|c|}
\hline Zona Actual/ZPD Identification & \multicolumn{3}{|c|}{ Class C } & \multicolumn{3}{|c|}{ Class C1 } \\
\hline \multicolumn{1}{|c|}{ Thematic } & G1 & G2 & G3 & G1 & G2 & G3 \\
\hline $\begin{array}{l}\text { Groups capable of completing } \\
\text { tasks independently through } \\
\text { cooperative work. }\end{array}$ & $\sqrt{ }$ & $\sqrt{ }$ & $\sqrt{ }$ & $\sqrt{ }$ & & $\sqrt{ }$ \\
\hline \multicolumn{1}{|c|}{ Transdisciplinary } & & & & & & \\
\hline $\begin{array}{l}\text { Groups capable of completing } \\
\text { tasks independently through } \\
\text { cooperative work. }\end{array}$ & & $\sqrt{ }$ & & & $\sqrt{ }$ & \\
\hline
\end{tabular}

This article will describe the group's ability to complete tasks and examples of the work of module 1. Module 1 entitled Description 4 Approach of Integrated Curriculum and Examples of Implementation. This module includes four subheadings. All materials are presented to students. However, individual and group tasks are limited to 2 integration. The task that students must do is thematic and transdisciplinary integration. Table 2 descibe general learning outcome using the TWSS model.

All of groups have completed the thematic integration tasks. Two groups completed the transdisciplinary task of integration within the group. One of the critical concepts in Vygotsky's theory is the zone of proximal development (ZPD). According to Vygotsky, the cognitive level at which children are able to solve problems independently is the zone of actual development. In contrast, the cognitive level at which children can solve problems with the help of others who are more capable is their ZPD. Beyond ZPD is a task that can not be achieved by children, even with the help of others who are more capable (Moreno, 2010: 90). According to Table 2, more groups have difficulty working with transdisciplinary skills and need more assited with capable adults.

The task of thinking in module 1 is about thematic integration, the task of individual module 1 include as follows: 1) analyze basic competence (BC) or scope of material four different subjects, if possible, in the same 
semester that can be bound by one theme. 2) Describe the interdisciplinary relationship according to the example figure in the module. 3) Create subject matter items or scope of material that has been selected. The task of thinking is

Table 3. Attitude Score Module 1

\begin{tabular}{|l|c|c|}
\hline \multicolumn{3}{|c|}{ Individual Responsibility Thinking Phase } \\
\hline Categories & $\sum$ Students & Percentage \\
\hline$\sum$ Excellent & 12 & $46 \%$ \\
\hline$\sum$ Good & 12 & $46 \%$ \\
\hline$\sum$ Moderate & 1 & $4 \%$ \\
\hline$\sum$ Poor & 1 & $4 \%$ \\
\hline
\end{tabular}

assessed from the aspect of attitude, namely the assessment of responsibility. Students get good grades when doing all the assigned questions. Here in Table 3 , are the results of the assessment of responsibilities.

Individual ideas are then discussed in groups to be chosen one as the work of the group. Each is enthusiastic about doing their work, see Table 3. Santrock (2011: 515) cites the results of Grolnick et al. (2002), and Stipeck (1996) studies that internal motivation and intrinsic interest in schoolwork increases if students have the choice and opportunity to take personal responsibility for their learning. Cave et al. (2005) cite Goldberg \& Stevens (2001) research; students who can participate actively in the learning process in the classroom become more passionate about their education.

\section{A. Examples of Group Product in the Working Phase}

Each group has two tasks, first choosing thematic integration ideas, second designing transdisciplinary integration. These are group duties in the working phase: 1) Conduct BC analysis in 3 different disciplines to discover and investigate real-world problems. 2) Explain and give examples of products that will result from the investigation. 3) Describe the interdisciplinary relationship according to figure in the module. 4) Able to develop the topic of learning into subject matter according to the example. 5) Design realworld based learning with a transdisciplinary approach according to the example. Table 4 below is an example of a work that can be done through cooperative learning in the working phase.

Table 4. Example Working Phase Multidisciplinary Design: Impact of High Rate Population

\begin{tabular}{|c|c|}
\hline $\begin{array}{c}\text { Basic Competencies on } 2013 \\
\text { Curriculum }\end{array}$ & Subject Matters \\
\hline $\begin{array}{l}\text { BC } 3.12 \text { Science for Grade } \\
\text { VIII } \\
\text { Describing the cause of high } \\
\text { rate population, which is } \\
\text { impacted on the } \\
\text { environment. }\end{array}$ & $\begin{array}{l}\text { 1. Level of natality \& mortality of } \\
\text { population in East Java Province. } \\
\text { 2. Decline in environmental quality } \\
\text { due to high population. } \\
\text { 3. Impairment of environmental } \\
\text { quality due to bad behavior to the } \\
\text { environment. }\end{array}$ \\
\hline $\begin{array}{l}\text { BC } 3.4 \text { Social science for } \\
\text { Grade VIII } \\
\text { Describing the forms and } \\
\text { nature of the dynamics of } \\
\text { human interaction with the } \\
\text { natural, social, cultural \& } \\
\text { economical. }\end{array}$ & $\begin{array}{l}\text { 4. Amount population and growth of } \\
\text { population. } \\
\text { 5. Population distribution and } \\
\text { migration. } \\
\text { 6. Population census. } \\
\text { 7. Population mobility. }\end{array}$ \\
\hline $\begin{array}{l}\text { BC 3.3 Civic education for } \\
\text { Grade VIII }\end{array}$ & $\begin{array}{l}\text { 8. Article abaut Marriage on the 28B } \\
1945 \text { Constitution. }\end{array}$ \\
\hline
\end{tabular}

\begin{tabular}{|c|c|}
\hline $\begin{array}{l}\text { Describing national law } \\
\text { order. }\end{array}$ & $\begin{array}{l}\text { 9. Law No.52 - on } 2009 \text { abaut Family } \\
\text { Planning. } \\
\text { 10. Dangerous free sex counseling.. } \\
\text { 11. Early marriage counseling. }\end{array}$ \\
\hline $\begin{array}{l}\text { BC } 3.11 \text { Mathematics for } \\
\text { Grade VIII } \\
\text { Understanding about data } \\
\text { organizing of } 2 \text { variables } \\
\text { using tables, bar graphs, pie } \\
\text { charts and line graphs. }\end{array}$ & $\begin{array}{l}\text { 12. Looking for data on the change of } \\
\text { population in East Java Province. } \\
\text { 13. Table data was changed into line } \\
\text { graphs, bars, and pie charts. }\end{array}$ \\
\hline
\end{tabular}

Theme idea by Group 2C has related issues in student daily life, see Table 4: The Impact of High Rate Population. Indonesia is among the fifth largest population in the world. Students could be learned high levels of population density with poor behavior will result in decreased environmental quality. Group 2 is pertained capable groups, this group can completing tasks independently. This finding is similar with Fernández et al. (2001: 15), which revealed that scaffolding could occur in groups where all members are in the same level of knowledge.

\section{B. Examples of Group Product in the Scaffolding Phase}

Tutors or lecturers will assisting students, if they have difficulties to complete assignments in their groups. The tutors come from the Department of Physics, and they perform the duties as experts to understand the field of physics studies. In junior high school curriculum in Indonesia's first largest number of subjects as biology, followed by physics and then chemist. Assistance by teacher allows students to pass through their proximal development zone.

Table 5. Example Group Product in Scaffolding Phase Transdisciplinary Design: Danger of Excessive Electricity Usage

\begin{tabular}{|c|c|}
\hline $\begin{array}{l}\text { Basic Competence in } 2013 \\
\text { Curriculum }\end{array}$ & Indicator \\
\hline $\begin{array}{l}\text { BC } 3.5 \text { Science for Grade IX } \\
\text { Describe the characteristics of } \\
\text { electrical circuits, the } \\
\text { transmission of electrical energy, } \\
\text { the sources of alternative } \\
\text { electrical energy (including } \\
\text { bioenergy), various efforts in } \\
\text { saving electrical energy, as well } \\
\text { as electrical technology used in } \\
\text { electrocardiography (EKG) and } \\
\text { hearing aids. }\end{array}$ & $\begin{array}{l}\text { 1. Explaining the definition of } \\
\text { electrical energy } \\
\text { 2. Explaining the sources of } \\
\text { electrical energy } \\
\text { 3. Explaining the danger of using } \\
\text { excessive electrical energy } \\
\text { 4. Explaining various efforts in } \\
\text { saving electrical energy }\end{array}$ \\
\hline $\begin{array}{l}\text { BC } 4.2 \text { Indonesian Language for } \\
\text { Grade VII } \\
\text { Arrange the text of observation, } \\
\text { descriptive, exposition, } \\
\text { explanation, and short story } \\
\text { according to the characteristics of } \\
\text { the text which will be made } \\
\text { either orally or in writing }\end{array}$ & $\begin{array}{l}\text { 5. Observing the use of electronic } \\
\text { appliances in some residents' } \\
\text { homes. } \\
\text { 6. Observation data in tabular } \\
\text { form. } \\
\text { 7. Arranging the observation } \\
\text { report according to the } \\
\text { instructions. }\end{array}$ \\
\hline $\begin{array}{l}\text { BC } 3.2 \text { Mathematics for Grade } \\
\text { VIII } \\
\text { Determine the variable value of a } \\
\text { linear equation of two variables } \\
\text { in a real context. }\end{array}$ & $\begin{array}{l}\text { 8. Comparing the consumption of } \\
\text { energy between efficient } \\
\text { electronic appliances with } \\
\text { electronic devices is not energy } \\
\text { efficient. } \\
\text { 9. Determine the equation value } \\
\text { of two variables based on } \\
\text { observation result. What is the } \\
\text { amount of electrical energy } \\
\text { that can be saved between } \\
\text { energy efficient electronic VS } \\
\text { non-energy saving devices? }\end{array}$ \\
\hline
\end{tabular}


This result is also compatible with the preliminary study findings in April 2017 that scaffolding works done well. These findings are shown through the presentation of the work of the group. All groups show mastery of making lesson plan with material related to physics. The average value of development lesson plan, 82. The average of pretest results 61,7 or $39 \%$ of 18 students passed the test. The average posted 80 results, 15 of 18 students or $83 \%$ passed the test. For the post-test, two students earned a score of 100 . Table 5 shows the results of group work helped by tutor group in this study.

Transdisciplinary is designed to investigate real-world problems. Students also challenged proposing various solutions creatively abaut problems in their investigate. The lesson uses the PBL model. Student's transdisciplinary design corresponds to the characteristics of a transdisciplinary approach by Alberta Education (2007: 10): Transdisciplinary emphasizes real life issues. There are two ways to implement a transdisciplinary approach, project-based learning and curriculum negotiation. Learning abaut knowledge and skills of different subject areas is the focus of the projects undertaken by students. Knowledge and skills are learned informally during students work on their projects. Table 6 The comparison between multidisciplinary dan transdisciplinary. Table 6 shows a comparison between multidisciplinary and transdisciplinary.

Table 6. Comparison Between Multidisciplinary and Transdisciplinary

\begin{tabular}{|c|c|}
\hline Multidisciplinary & Transdisciplinary \\
\hline Teachers teach their subjects. & \multirow{5}{*}{$\begin{array}{l}\text { Learning was conduct by the } \\
\text { science teacher. The lesson uses } \\
\text { the PBL model. } \\
\text { Transdisciplinary is designed to } \\
\text { investigate real-world problems. } \\
\text { Students are also challenged } \\
\text { creatively proposing various } \\
\text { solutions to their investigate } \\
\text { problems. } \\
\text { Learning the knowledge and skills } \\
\text { of different subject areas were the } \\
\text { focus of the projects undertaken by } \\
\text { students. Knowledge and skills } \\
\text { have learned informally during } \\
\text { students work on their projects. }\end{array}$} \\
\hline $\begin{array}{l}\text { Science teacher, teach about: } \\
\text { BC } 3.12 \text { Science for Grade VIII } \\
\text { Describing the cause of population } \\
\text { development and its impact on the } \\
\text { environment. }\end{array}$ & \\
\hline $\begin{array}{l}\text { Social science teacher, teach about: } \\
\text { BC } 3.4 \text { Social science for Grade VIII } \\
\text { Describing the forms and nature of } \\
\text { the dynamics of human interaction } \\
\text { with natural, social, cultural \& } \\
\text { economical. }\end{array}$ & \\
\hline $\begin{array}{l}\text { Civil education teacher, teach about: } \\
\text { BC } 3.3 \text { Civic education for Grade } \\
\text { VIII } \\
\text { Describing national law order. }\end{array}$ & \\
\hline $\begin{array}{l}\text { Math teacher, teach about: } \\
\text { BC } 3.11 \text { Mathematics for Grade VIII } \\
\text { Understanding about data organizing } \\
\text { of } 2 \text { variables using tables, bar } \\
\text { graphs, pie charts and line graphs. }\end{array}$ & \\
\hline
\end{tabular}

\section{Reviewing Work on the Sharing Phase}

The sharing phase activity is presenting the group's work through class discussions. Based on this phase lecturers and

\section{REFERENCES}

[1] Titus, H. (1959). Living Issues in Philosophy. 3ed. New York: American Book Company. students could be evaluating the group's products. Mistakes works done by students on module 1 as follows:

1. Students have not been able to distinguish between multidisciplinary and transdisciplinary approach.

2. Multidisciplinary or thematic designs not being in the same grade and semester.

3. Transdisciplinary problems studied through learning literature not lead students to real-world investigations.

4. Transdisciplinary based on real-world problems, but their autcome very difficult to junior high school.

Based on the sharing phase result, students are given scaffolding to be able to correct their mistakes. Students revise the problematic task with the help of tutor or lecturer. Through various phases of TWSS model students are able to work on tasks module 1. Scaffolding is given to help students achieve the competence of module 1 that is understanding the relationship of science with the field of study in another discipline cluster. Many factors influence successfully implementation of integrated science curriculum one of which is the quality of teachers. Teachers must be get adequate preparation following the tasks it carries. The preparation is gained through education as well as professional development in which teachers obtain knowledge content related to the curriculum (Huntley, 1998; Knudson, 1973; Leung, 2006; Palmer, 1991; Southern Region Education Board, 1998; Harrel, 2010: 1).

\section{CONCLUSION}

Based on the description of research results, TWSS model could helped students mastering the competence of module 1: understanding the relationship of science with the field of study in other discipline clusters. Students are able to design multidisciplinary (thematic) and transdisciplinary integration. Thematic integration can also be used to understand concepts related to real-world problems. Example: impact of high rate population. Transdisciplinary is defined as a process characterized by the integration of various disciplines to understand issues or problems. Characteristic of transdisciplinary is train students to investigate real-world problems through the PBL model.

According to the mandate of the curriculum, the student should gain experience in learning to solve problems with the transdisciplinary approach. The results in the sharing phase, especially the numbers 2 and 3 indicate that biology education students have difficulty understanding transdisciplinary integration. This concept should be introduced to biology/science education students. Understanding the content demanded by the curriculum will help teachers to be able to perform theirs duties.

[2] Indrawati. (2009). Integrated Learning Model in Elementary School for Elementary Teachers. Bandung: Center for the Development and Empowerment of Educators and Science Teachers (P4TK-IPA).

[3] Susiwi. S. (2007). Life Skill. Chemistry Learning Planning Course Handout (KI 502). Bandung: Department of Chemistry Education Faculty of Mathematics \& Science Universitas Pendidikan Indonesia. 
[4] Widhy, Purwanti. (2013). Integrative Science to Realize 21st Century Skill in Junior High School Science Lessons. Presented at the National Conference FMIPA UNY 2013.

[5] Unesco. (1998). Transdisciplinarity Stimulating Synergies, Integrating Knowledge. Unesco: Division of Philosophy and Ethics

[6] Branch, Robert Maribe. (2010). Instructional Design: The ADDIE Approach. [electronic resource] by [author.]; SpringerLink (Online service).

[7] Kemendikbud. (2013). The attachment of Regulation of Permendikbud No. 68 the Year 2013 on Basic Framework and Structure of Junior High School Curriculum/Madrasah Tsanawiyah. Jakarta: Kemendikbud.

[8] Kemendikbud. (2016). Copy of Attachment to Regulation of Permendikbud No. 22 The year 2016 on Standard Process of Primary and Secondary Education. Jakarta: Kemendikbud.

[9] Evagorou, M; Devrim Guven \& Ebru Mugaloglu. (2014). Preparing Elementary and Secondary Pre-Service Teachers for Everyday Science. Science Education International Vol. 25, Issue 1, 2014, 68 78.

[10] Alberta Education, Alberta, Canada. (2007). Primary Programs Framework - Curriculum Integration: Making Connections. Primary Programs Framework for Teaching and Learning. Alberta Education: Alberta, Canada.

[11] Kemendikbud. (2016). Curriculum 2016: Syllabus SMP / MTs Science Subject. Jakarta: Kemendikbud.

[12] Moreno, Roxana. (2010). Educational Psychology. Copyright (C) 2010 John Wiley \& Sons, Inc.

[13] Permendiknas. (2007). Regulation of the Permendiknas No. 16 Year 2007 on Academic Qualification Standards and Teacher Competencies. Jakarta: Kemendiknas.

[14] Fernandez Manuel; Rupert Wegerif; Neil Mercer, Sylvia RojasDrummond. (2001). Re-conceptualizing "Scaffolding" and the Zone of Proximal Development in the Context of Symmetrical Collaborative Learning. Journal of Classroom Interaction Vol. 36, No. 2. 2001.

[15] Cave, T., Ludwar, J., and Williams, W. (2005). Brain-Based Learning. Literatur Synopsis. Coordination \& editing by Dr. David Townsend. Univ of Lethbridge.

[16] https://education.alberta.ca/apps/aisi/literature/pdfs/bbased_learning.p df

[17] Santroct, John.W. (2007). Psikologi Pendidikan. Edisi Kedua. Alihbahasa oleh Tri Wibisono BS. Jakarta: Kencana Prenada Media Group.

[18] Harrell, Pamela Esprívalo. (2010). Teaching an Integrated Science Curriculum: Linking Teacher Knowledge and Teaching Assignments. Issues in Teacher Education Volume 19, Number 1, Spring 2010.G. Eason, B. Noble, and I. N. Sneddon, "On certain integrals of LipschitzHankel type involving products of Bessel functions," Phil. Trans. Roy. Soc. London, vol. A247, pp. 529-551, April 1955. (references) 